\title{
Customer Solutions Management (CSM) Empirical Model based on European Machine Building Sector Experience
}

\author{
Vit Chlebovsky
}

Brno University of Technology

Kolejni 4, CZ-612 00 Brno, Czech Republic

E-mail.chlebovsky@fbm.vutbr.cz

cross $^{\text {ref }}$ http://dx.doi.org/10.5755/j01.ee.27.5.14491

There can be seen growing demand for customized solution offers prepared by companies on both B2B and B2C markets. While this concept is well developed in some B2B sectors it is not that often on B2C markets. Recent rapid technology development gives more and more possibilities to increase production flexibility in more production sectors. This will lead to increasing the level of product customization shortly.

Purpose of this article is to introduce an empirical model of Customer Solutions Management that has been created based on the long term experience in machine building sector within the EU. The experience is documented by qualitative case study research performed in five European companies involved in supply chain within the machine building sector - from component production through distribution to machine building. Selected companies represent size range from large corporation to micro business. The research was performed in the period from 2012 to 2015 by observations and in-depth interviews with all level managers in all researched companies. Prior to the qualitative research, secondary data research in publications in order to analyze the sector in complexity was performed as well. The research proves the increasing demand for individualized product solutions from customers.

Results of the research were used to create empirical model of Customer Solutions Management - business concept covering identification, development, production and delivery of customized product solutions to customers.

Keywords: Customer Solutions, Relationship Marketing, Product Customization, Market Orientation, Product Management, Machine Building Sector, Solution Management.

\section{Introduction and Conceptual Background}

For many decades the competitive advantage was primarily based on technological aspects connected with capabilities to develop and produce. Thus, capital, raw materials, production capacity and capabilities or human resources were scarce (Kellen, 2003). The situation has changed dramatically within past few decades with the international business environment globalization. Increased competitiveness in the environment increased the focus on customer's requirements (Franceschini et al., 2015) and relationship processes (Tuli et al., 2007). Thus, the new scarcity can be seen in superior customer knowledge (Kellen, 2003) and capability to offer solutions (Biggemann et al., 2013). Efforts towards customer requirement knowledge led to the rapid development of relationship marketing and customer relationship management - CRM (Payne \& Frow, 2005). CRM is a great help to companies to increase their business competitiveness. On the other hand, CRM concentrates primarily on customers outside the company, but stronger internal focus on solution development processes is also crucial (Bennett et al., 2001).

In order to develop complex approach methodology to customer solutions management, several managerial disciplines have to be combined together into one working concept of CSM. Managerial discipline combination structure and its dynamic cyclic functionality in four phases is shown in a conceptual scheme in Figure 1. Customer solutions management concept goes from strong focus on customer requirements in phase 1, through solution development in phase 2 and its delivery and implementation in phase 3 to phase 4 focused on success measurement, control and requirement revisions for the next complete cycle.

Strong orientation on customers started already back in $20^{\text {th }}$ century, documented in Strong (1925). More detailed definition of customer orientation was then described in Saxe \& Weitz, (1982). They define customer oriented selling as practical application of the marketing concept on the individual personal interaction between sales person and customer. They also introduced SOCO Scale (Sales Orientation - Customer Orientation Scale) for the measurement of customer orientation. Sales approach of customer orientation is typically sorted into relationship selling and adaptive selling (Wilson, 1995), as the focus on customer expectations has been seen as a very important factor of customer orientation (Weitz, 1981).

Market orientation business approach was firstly introduced in Drucker (1954), where marketing oriented approach was introduced as an alternative to product oriented concept. More systematic concept of market orientation was presented by Webster (1988) and later also by Kohli \& Jaworski (1990), Jaworski \& Kohli (1996), Narver \& Slater (1990) and by Ruekert (1992). All these authors present influence of company market orientation to its business performance. Kohli \& Jaworski (1990) also define basic principles of market orientation as customer focus, competition focus, stakeholder focus and focus on company flexibility. 


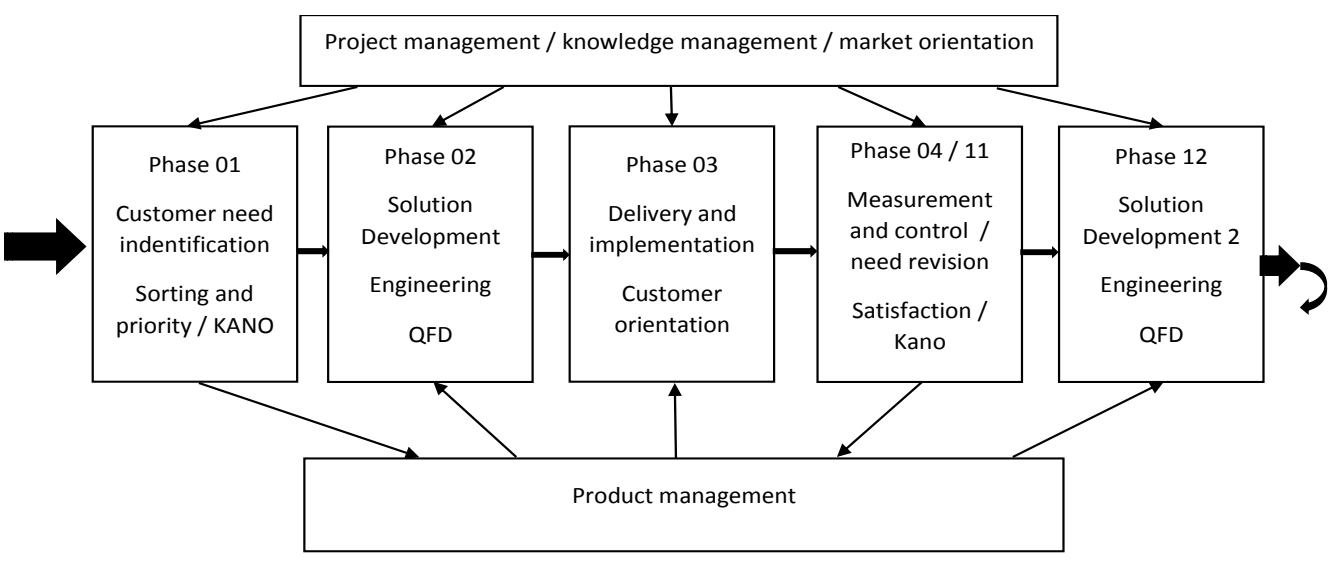

Figure 1. Customer Solutions Management (CSM) Conceptual Scheme

Two models for market orientation measurement were developed - MKTOR by Narver \& Slater (1990) and MARKOR by Kohli, Jaworski \& Kumar (1993).

The primary concentration of both models is on customers. While MKTOR is primarily based on measurement and feedback, MARKOR emphasizes proactivity of the personnel throughout the company structure. With the personnel activity many barriers of market orientation success are connected. Kanovska \& Tomaskova (2012) show that internal barriers connected with the top management activities are often the reason why companies fail in the market orientation implementation. Lo et al. (2015) describe the relation between leadership and market orientation.

Even though there are described contradictions of customer and market orientation based on internal conflicts between sales and marketing departments in the company (Kotler, Rackham \& Krishnaswamy, 2006), there are also joint approaches of both concepts (Shapiro, 1988).

Important base of customer solution focus is in identification and prioritization of customer needs. Identification and consequent prioritization of customer requirements is part of various customer satisfaction models. Kano et al. (1984) are working with must-be, onedimensional and attractive requirements for the products. While must-be and one-dimensional requirements are primarily connected with core and total product, attractive requirements go towards augmented product. More complex approach combining customer requirement identification, prioritization and product development can be seen in Total Quality Management (TQM) models (Akao, 1990). Many authors are working with Quality Function Deployment (QFD) model based on TQM approach. QFD (Akao, 1990; Clausing, 1994; Cohen, 1995) is a concept of product development based on superior customer requirement knowledge working with the so called House of Quality Matrix (Wasseman, 1993). Some authors are combining together KANO and QFD concepts (Matzler \& Hinterhuber, 1998; Tan \& Pawitra 2001) to get a more effective product development process.

After customer requirement identification and prioritization within phase 1 , a solution development has to be processed. Production oriented companies in particular have to be strong in engineering to ensure effective innovations (Garcia \& Calantone 2002). Published research confirms positive influence of the increased priority of product innovation on the firm's profitability (Baker \& Sinkula, 2015).

Working in innovation cycles requires parallel activities in marketing and engineering. Thus, concurrent engineering and simultaneous engineering were introduced (Ma et al. 2008). Both concepts enable parallel innovation cycle management and higher flexibility of the organization leading to lean production concepts (Womack et al., 1990).

In order to ensure required flexibility and efficiency within the organization, strong project based management is crucial. Such companies are called Project Based Firms (PBF) (Whitley, 2006). Jones et al. (1997) show that strong project based management leads to lighter organizational structure of the company. Several authors also describe the relation between project based management and marketing, primarily seen in relationship marketing and networking (Webster, 1992).

Besides project based management of the company, strong focus on product management and effective knowledge management is also important inside the organization. Product management is typically seen on process base of Product Lifetime Management (PLM) (Gorchels 2003). Successful product management requires strong personality of product managers (Prevel Katsanis et al., 1996), because of unclear defined competences in the organization whereby product managers have to coordinate activities through various company departments. Major processes that have to be handled by a product manager are branding, marketing communication, product stock planning, pricing management and distribution management (Tyagi \& Sawhney, 2010).

Effective knowledge management gives to company strong tool for internal know-how and experience real time sharing (Wasko \& Faraj, 2005).

Coordinated use of described concepts and tools towards customer solutions is not seen often in the companies. It is more likely in B2B oriented companies than in B2C sector. Quite often it is also a scope of small and 
medium sized enterprises using their higher flexibility advantage but at the same time working with financial, assets and human resources limitations (Schuller \& Videcka, 2016).

Rapid technology development within past years gives more and more possibilities to increase production flexibility in more and more production sectors. This will lead soon to increasing level of product customization also in higher quantity production sectors.

In order to prepare inspiration base for Customer Solution Management orientation, the following qualitative research was done and CSM empirical model was created. The main objective of this paper is to introduce an empirical model of Customer Solutions Management created based on long term experience in machine building sector within the European Union. The experience is documented by qualitative case study research performed in five European companies involved in product supply chain within the machine building sector from component production through distribution to machine building. The research was performed in the period from 2012 to 2015 by observations and in-depth interviews with managers of all levels in all researched companies. In order to analyze the sector in complexity, also secondary research was performed through publications.

Results of the research were used to create the empirical model of Customer Solutions Management which is used to employ a new business approach. This approach can be used in many companies not only in B2B but more and more often in B2C sector as well.

\section{Research Methodology}

Qualitative research is seen as a very useful tool to observe real conditions and situations in real environments. What is important is the scope of the problem from the subject researched's perspective. Qualitative research works with the research question only and does not test the hypothesis. Qualitative research based on case studies is used very often to observe, describe and prove research models in specific organizations (Eisenhardt, 1989, 1991). Thus case study research was chosen in this situation.

There were five companies selected that represent a complete supply chain in the machine building sector from component production through to distribution to machine building. Selected companies also represent different size categories from large global corporations to medium and small businesses to micro companies. They are located in several European countries: Switzerland, Germany, Austria and the Czech Republic.

The research case study template was created prior to the research's execution, primarily covering the following groups of information: company business basics, product group characteristics, marketing and sales process characteristics, product customization capabilities, strategic development plans and competition characteristics. All groups of information described were specifically focused on actual and future capabilities of the companies in customer solutions development.

The data collected for the case study protocols are from three major sources:

1. Secondary source research within the past four years - primarily financial reports, annual reports (if applicable) and the Amadeus database (Bureau Van Dijk, 2015) were used.

2. Observations inside all five companies in regularly timed intervals within the period 2012-2015.

3. In-depth interviews with company managers at all management levels in all companies. Interviews were performed during the period July to October 2015.

The following companies were researched (their names are modified to keep sensitive information confidential):

$\mathrm{ABC}$ Servo $\mathrm{GmbH}$ is a German manufacturer of components for drive technologies and industry automation located near Munich. The company has approx. 200 employees and an annual turnover close to 23 mil. EUR.

$\mathrm{KK} \mathrm{GmbH}$ is an Austrian company focusing on the trade and engineering of components and subsystems in the field of drive technology. The company is active in Austria and also other countries within the CEE region (Czech Republic, Poland, Slovakia and Hungary). KK GmbH is a distributor of several world leading producers from Germany, Switzerland, USA, Japan or Korea.

MM AG is Swiss producer of electric DC and EC motors, gearboxes, drive electronics and other accessories. The company started approx. 50 years ago and built up a global market presence through a network of daughter companies (on major markets) and distributors.

DMC s.r.o. is a Czech producer of special machines and entire production technologies and respective automation. It is a small company located in the Czech Republic. Founded in 1995, it has gone through dynamic development. Turnover reached 4 mil. EUR in 2015. The company has approx. 30 employees at the moment.

MNPR is a Czech producer of edge banding machines. It is a micro business located in the Czech Republic. The company started in 1988 (just before the political changes in Eastern Europe) and concentrates on specialized machine production.

\section{Research Data Summary and Analysis}

Information collected through case studies is summarized in Table 1 showing the actual situation of the companies researched and also in Table 2 that summarizes the future plans and visions of the company managements in order to stay sustainably competitive in their markets.

Table 1

Summary of the Case Studies

\begin{tabular}{|c|c|c|c|c|c|}
\hline & MM AG & ABC Servo GmbH & KK GmbH & DMC s.r.o. & MNPR \\
\hline $\begin{array}{l}\text { Company size / } \\
\text { number of employees }\end{array}$ & $\begin{array}{l}\text { large / 2000+ } \\
\text { worldwide }\end{array}$ & $\begin{array}{l}\text { Medium / } 200 \text { in } \\
\text { Germany }\end{array}$ & $\begin{array}{c}\text { Medium / } 20 \text { in } \\
\text { Austria and Czechia }\end{array}$ & $\begin{array}{l}\text { Small / } 20 \text { in } \\
\text { Czechia }\end{array}$ & Micro / 10 in Czechia \\
\hline $\begin{array}{l}\text { Annual turnover (mil. } \\
\text { EUR) }\end{array}$ & $250+$ & 25 & 12 & 4 & 1,5 \\
\hline Product type & components & Components & Components, services & Systems / machines & Systems / machines \\
\hline
\end{tabular}


Vit Chlebovsky. Customer Solutions Management (CSM) Empirical Model based on European Machine Building...

\begin{tabular}{|c|c|c|c|c|c|}
\hline & MM AG & ABC Servo GmbH & KK GmbH & DMC s.r.o. & MNPR \\
\hline Internal focus & Product technology & $\begin{array}{c}\text { Customized solutions, } \\
\text { technology }\end{array}$ & Customized solutions & $\begin{array}{l}\text { Customized } \\
\text { solutions }\end{array}$ & Product technology \\
\hline Flexibility & Limited, stable & Limited, decreasing & Medium, decreasing & High, stable & Medium, stable \\
\hline Market orientation & $\begin{array}{l}\text { Insufficient internal } \\
\text { coordination }\end{array}$ & $\begin{array}{l}\text { Insufficient } \\
\text { orientation on } \\
\text { competition }\end{array}$ & Good & $\begin{array}{l}\text { Insufficient } \\
\text { orientation on } \\
\text { competition }\end{array}$ & Good \\
\hline Project management & $\begin{array}{l}\text { Internal projects only } \\
\text { (R\&D, ICT, } \\
\text { processes) }\end{array}$ & $\begin{array}{l}\text { Internal projects only } \\
\text { (R\&D, ICT, } \\
\text { processes) }\end{array}$ & $\begin{array}{l}\text { Key customer } \\
\text { oriented }\end{array}$ & $\begin{array}{l}\text { Key customer } \\
\text { oriented }\end{array}$ & Insufficient \\
\hline Engineering & Yes & Yes & No & Yes & Yes \\
\hline Product management & Yes & $\begin{array}{l}\text { Yes but limited to } \\
\text { some applications } \\
\text { (medical) }\end{array}$ & No & No & Limited \\
\hline Product complexity & Good, growing & Good, stable & $\begin{array}{l}\text { Insufficient portion of } \\
\text { services (primarily } \\
\text { SW) }\end{array}$ & Good & Medium \\
\hline $\begin{array}{l}\text { Capability of product } \\
\text { individualization }\end{array}$ & $\begin{array}{l}\text { Limited but growing } \\
\text { with configurable } \\
\text { products }\end{array}$ & Good, stable & $\begin{array}{l}\text { Insufficient } \\
\text { engineering }\end{array}$ & High & Limited \\
\hline $\begin{array}{l}\text { Knowledge } \\
\text { management }\end{array}$ & Good stable & $\begin{array}{c}\text { Insufficient } \\
\text { knowledge sharing } \\
\text { platform }\end{array}$ & $\begin{array}{c}\text { Insufficient } \\
\text { knowledge sharing } \\
\text { platform }\end{array}$ & $\begin{array}{c}\text { Insufficient } \\
\text { knowledge sharing } \\
\text { platform }\end{array}$ & $\begin{array}{c}\text { Insufficient } \\
\text { knowledge sharing } \\
\text { platform }\end{array}$ \\
\hline Innovation orientation & $\begin{array}{c}40 \text { registered patents } \\
\text { Annually invested } 9 \\
\% \text { of turnover into } \\
\text { R\&D }\end{array}$ & $\begin{array}{l}29 \text { registered patents } \\
\text { Annually invested } 6 \% \\
\text { of turnover into R\&D }\end{array}$ & $\begin{array}{l}1 \text { registered patent } \\
\text { No } R \& D \text { investments }\end{array}$ & $\begin{array}{c}21 \text { registered } \\
\text { patents } \\
\text { Annually invested } \\
17 \% \text { of turnover } \\
\text { into R\&D }\end{array}$ & $\begin{array}{c}0 \text { registered patents } \\
\text { Annually invested } \\
15 \% \text { of turnover into } \\
\text { R\&D }\end{array}$ \\
\hline $\begin{array}{l}\text { Trends of financial } \\
\text { ratios }\end{array}$ & $\begin{array}{l}\text { Stable even with CHF } \\
\text { Exchange rate issues } \\
\text { and fluctuations }\end{array}$ & Unstable & Decreasing margins & $\begin{array}{c}\text { Growing in past } 5 \\
\text { years }\end{array}$ & unstable \\
\hline Major competition & $\begin{array}{c}\text { FHB AG } \\
\text { Asian copies }\end{array}$ & $\begin{array}{c}\text { NG Inc } \\
\text { Asian copies } \\
\text { New technologies of } \\
\text { contactless } \\
\text { transmissions }\end{array}$ & $\begin{array}{l}\text { ELR GmbH, RAV } \\
\text { s.r.o. } \\
\text { Automation System } \\
\text { companies (Siemens, } \\
\text { Rockwell...) }\end{array}$ & $\begin{array}{c}\text { Many Czech } \\
\text { producers of special } \\
\text { machines } \\
\text { Robotics of the } \\
\text { manufacturing in } \\
\text { the future }\end{array}$ & $\begin{array}{l}\text { Asian copies } \\
\text { 3D printing } \\
\text { technologies in the } \\
\text { future }\end{array}$ \\
\hline
\end{tabular}

Table 1 shows that production companies are still focusing more on technology excellence rather than customer requirements. The companies researched have limited flexibility in general and they do not use project based organization towards product and solution development. On one side they have a good level of product complexity but their product offer individualization capability is rather limited.

Table 2

\section{Key Factors and Tools Used By Companies to Support Sustainability of their Competitiveness}

\begin{tabular}{|c|c|c|}
\hline Company & $\begin{array}{l}\text { Key factors of the sustainable competitiveness according } \\
\text { to company management }\end{array}$ & $\begin{array}{l}\text { Key tools of the sustainable competitiveness according to } \\
\text { company management }\end{array}$ \\
\hline MM AG & $\begin{array}{l}\text { Excellent product technology } \\
\text { Product modularity enabling offer individualization } \\
\text { Complex product offer - drive system } \\
\text { Short delivery time - especially for low quantities for } \\
\text { samples and prototyping } \\
\text { Excellent global services and support to customers }\end{array}$ & $\begin{array}{l}\text { Continuous innovation / Engineering } \\
\text { Product management } \\
\text { Isle production organization } \\
\text { Global electronic trade } \\
\text { Built up own distribution network, eliminate external } \\
\text { distributors }\end{array}$ \\
\hline ABC Servo GmbH & $\begin{array}{l}\text { Capability to offer customized product for any application } \\
\text { Excellent product technology } \\
\text { Reasonable delivery time } \\
\text { Customer service and support }\end{array}$ & $\begin{array}{l}\text { Project management } \\
\text { Product management } \\
\text { Engineering } \\
\text { Eliminate external production cooperations } \\
\text { Own global distribution network }\end{array}$ \\
\hline KK GmbH & $\begin{array}{l}\text { Customer requirements knowledge } \\
\text { Capability to offer optimal solution for the application - } \\
\text { independent to particular producer or technology } \\
\text { Excellent support and services to customers in both } \\
\text { hardware and software } \\
\text { Knowledge of competition }\end{array}$ & $\begin{array}{l}\text { Communication tools } \\
\text { Network of suppliers covering various technologies } \\
\text { Engineering } \\
\text { Competent customer support } \\
\text { Competent market analysis }\end{array}$ \\
\hline DMC s.r.o. & $\begin{array}{l}\text { Technology know-how } \\
\text { Capability to offer customized solution to customers } \\
\text { Additional services including financial }\end{array}$ & $\begin{array}{l}\text { Innovations / Engineering } \\
\text { Project based oriented company organization }\end{array}$ \\
\hline MNPR & $\begin{array}{l}\text { Technology know-how } \\
\text { Customer knowledge and knowledge of their requirements } \\
\text { Complementary products }\end{array}$ & $\begin{array}{l}\text { Engineering } \\
\text { Own distribution network } \\
\text { Product management }\end{array}$ \\
\hline
\end{tabular}


When it comes to the future orientation shown in Table 2 , companies perceive the importance of the capability to offer customized product solutions to customers and also the importance of good customer knowledge and communication.

\section{Customer Solutions Management (CSM) Empirical Model}

As shown by the conceptual scheme and outcomes of qualitative research executed, it is recommended to make product innovations in cycles consisting of four consequent phases. It is also evident out of the case studies that those major innovation cycles should be primarily focused on innovations of the systemic base of core and total product. This systemic base should be flexible enough to enable further individualization and customization of the final product proposed to each and every customer. So there are longer innovation cycles related to cyclic innovations of the product systemic base. Besides these cycles there can be seen short project cycles focused on development and delivery of customized solutions to particular customers.
These cycles are significantly shorter and typically there are more of these cycles running in parallel - one cycle for each project of a customized solution development and delivery to the customer. These two types of cycles are further called Product innovation cycles for cycles of systemic product base innovations and cycles of customer needs for customized solution development and delivery projects. The basic characteristics of both cycles are shown in Table 3.

In order to present the Customer Solutions Management empirical model in a clear graphical form, the spiral model was used. The spiral concept of the model was inspired by two cyclic models often used in the ICT sector. The first one is the so-called COBIT (Control Objectives for Information and Related Technology). It is a framework created by ISACA for information technology (IT) management and IT governance. The second one is a software development spiral model introduced by Barry Boehm in Boehm (1988) showing the software development process in spiral iterations.

Summary of the CSM Cycles

\begin{tabular}{|c|c|c|c|}
\hline \multicolumn{2}{|c|}{ Product innovation cycle } & \multicolumn{2}{|c|}{ Cycle of customer needs } \\
\hline \multicolumn{4}{|c|}{ Identification and analysis of customer needs } \\
\hline $\begin{array}{l}\text { General and system } \\
\text { requirements } \\
\text { (core product) }\end{array}$ & Characteristics & $\begin{array}{l}\text { Individual requirements } \\
\text { (augmented product) }\end{array}$ & Characteristics \\
\hline KANO Methodology & $\begin{array}{c}\text { Identification, categorization, } \\
\text { prioritization of the customer } \\
\text { requirements / needs } \\
\text { General and system product requirements } \\
\text { are received }\end{array}$ & $\begin{array}{l}\text { Individual requirement } \\
\text { identification }\end{array}$ & $\begin{array}{l}\text { Particular basis for proposal preparation to } \\
\text { each and every customer. }\end{array}$ \\
\hline \multicolumn{4}{|c|}{ Research and development of customer solution } \\
\hline $\begin{array}{l}\text { General and system } \\
\text { requirements } \\
\text { (core product) }\end{array}$ & Characteristics & $\begin{array}{l}\text { Individual requirements } \\
\text { (augmented product) }\end{array}$ & Characteristics \\
\hline $\begin{array}{l}\text { QFD with use of } \\
\text { KANO Method }\end{array}$ & $\begin{array}{l}\text { Product development based on known } \\
\text { customer requirements: } \\
\text { Identification of the requirements for } \\
\text { product construction, relation matrix - } \\
\text { how construction changes can influence } \\
\text { product parameters? }\end{array}$ & Project management & Each customer requested solution $=$ project \\
\hline Engineering & $\begin{array}{l}\text { Application of all the technology know- } \\
\text { how and capabilities of the company } \\
\text { In order to develop core product }\end{array}$ & Knowledge management & Sharing of existing solutions and capabilities \\
\hline Product management & $\begin{array}{l}\text { Complex marketing mix - in this phase } \\
\text { concentration on product }\end{array}$ & Engineering & $\begin{array}{l}\text { Application of all the technology know-how } \\
\text { and capabilities of the company } \\
\text { In order to finalize individual product for } \\
\text { customer. }\end{array}$ \\
\hline \multicolumn{4}{|c|}{$\begin{array}{ll}\text { III. } & \text { Solution delivery and implementation }\end{array}$} \\
\hline $\begin{array}{l}\text { General and system } \\
\text { requirements } \\
\text { (core product) }\end{array}$ & Characteristics & $\begin{array}{l}\text { Individual requirements } \\
\text { (augmented product) }\end{array}$ & Characteristics \\
\hline Product management & $\begin{array}{l}\text { Complex marketing mix }- \text { in this phase } \\
\text { concentration on communication, } \\
\text { distribution and pricing }\end{array}$ & Project management & $\begin{array}{l}\text { Each customer requested solution = project } \\
\text { Concentration on delivery and } \\
\text { implementation of the solution to customer }\end{array}$ \\
\hline \multicolumn{4}{|c|}{ IV. Measurement of the solution success } \\
\hline $\begin{array}{l}\text { General and system } \\
\text { requirements } \\
\text { (core product) }\end{array}$ & Characteristics & $\begin{array}{l}\text { Individual requirements } \\
\text { (augmented product) }\end{array}$ & Characteristics \\
\hline KANO methodology & $\begin{array}{l}\text { Next cycle of customer needs } \\
\text { identification for basic product }\end{array}$ & Project management & $\begin{array}{c}\text { Each customer requested solution }=\text { project } \\
\text { Concentration on measuring and checking the } \\
\text { project success }\end{array}$ \\
\hline
\end{tabular}


The Customer Solutions Management spiral model in Figure 2 presents cycles of systemic core and total product innovations. It can be seen based on the research described above that each next innovation cycle brings, of course, an increase in total absolute innovation related costs on one side but at the same time the relative increase of costs related to each next innovation decreases. It also shows that each next innovation cycle increases significantly the number of possible combinations of available individual solutions for customers and thus product flexibility increases cycle by cycle. This also leads to a decrease of costs related to individual customer solution development and, last but not least, to faster development and implementation of individual solutions for customers. The efficiency of innovation cycle progress is based and dependent on the smart use of all internal resources in the company knowledge base, internal processes, technologies and last but not least personnel.

\section{Discussion and Implications}

The qualitative research performed in the case studies described of five companies within the machine building sector in Europe shows the increasing importance of focusing on offering individualization to customers as a key factor influencing sustainable competitiveness. Thus the empirical model of Customer Solutions Management is introduced in this paper showing possible efficient ways to continuously keep full capability of the company in development and implementation of individual customer solutions. As mentioned in the previous paragraphs, such a business concept focusing on individualization can often be seen in the B2B sector. It is not yet that common in B2C. On the other hand, there are technological developments significantly increasing the possibilities of product individualization in the B2C sector as well. Brynjolfsson \& McAfee (2014) mention three basic technology oriented principles with a strong impact on business concepts. It is vital to understand the nature of technological progress in the era of digital hardware, software and networks. As key characteristics Brynjolfsson \& McAfee see technological progress to be exponential, digital and combinatorial. Its exponential growth is connected with so called Moore's law based on the observation that the number of transistors in a dense integrated circuit doubles approximately every two years. It is empirically proven that due to this rule computing power and digital storage capacity also double. This leads to the second characteristics of digital progress. All new developed content and an increasing majority of older content is available in digital form and is available for immediate and easy sharing at very low cost. Both these principles lead to combinatorial progress in technologies. In other words, from a particular business perspective, companies are getting great tools for efficient individualized product development. Progress is intensified by easier access to new production technologies based on robotics and 3D printing. Those technologies are increasing the possibilities of individualized production in the $\mathrm{B} 2 \mathrm{C}$ sector as well.

Due to the technological progress discussed, I am convinced that the Customer Solutions Management empirical model present will become a conceptual base for consumer business oriented companies as well.

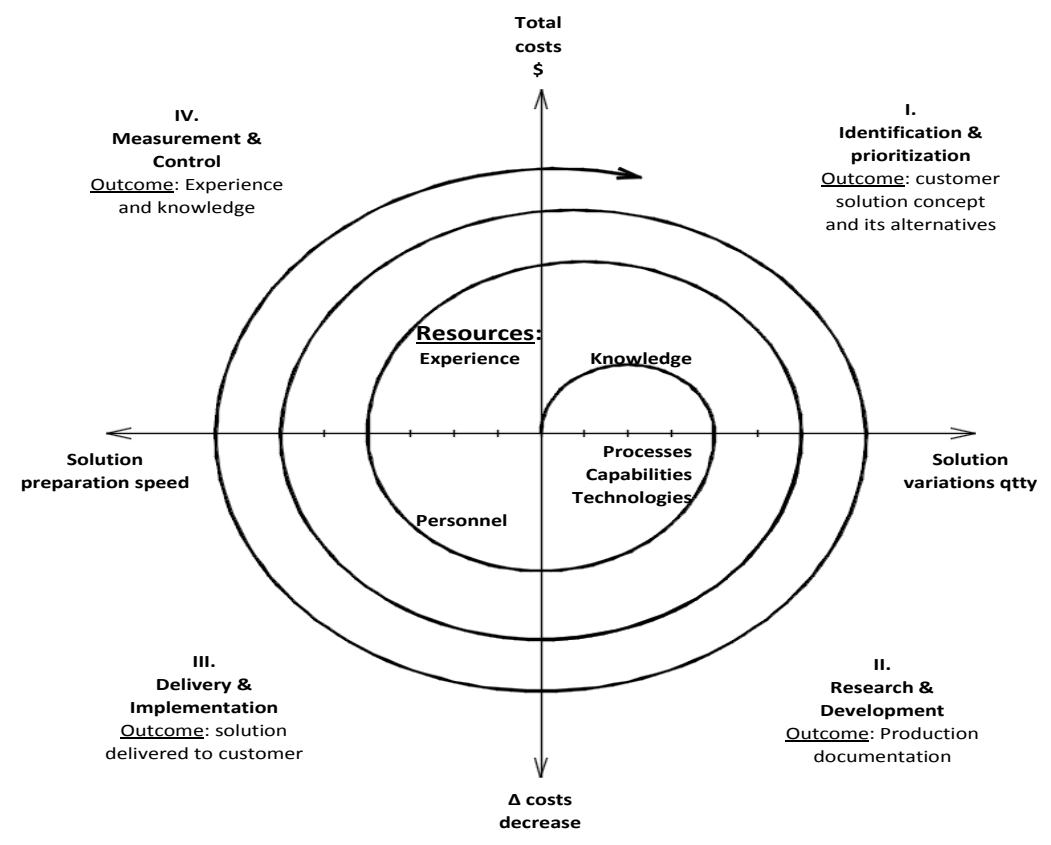

Figure 2. Customer Solutions Management Empirical Model

\section{Conclusions}

The purpose of this article was the development and presentation of the Customer Solutions Management (CSM) empirical model. The model introduced is based on qualitative research executed by case studies mapping experience through supply chains in the European machine building sector. There were five particular companies selected for the case studies, representing various positions within the supply chain from component production, 
through distribution to machine building. Companies also represent a range of sizes from large global corporations to micro businesses. The research proves an increasing demand for individualized product solutions from customers. This demand increase is reflected in the strategic plans and decisions of researched companies. The empirical model introduced of Customer Solutions Management could be a helpful guideline for companies to increase their flexibility and capability to offer, develop and deliver individualized product solutions to their customers. The model is based on case study outcomes and also reflects recent technological premises increasing the possibilities of efficient individualized product development. Presented CSM model is inspired by the COBIT cyclic project management model and the spiral iteration model used in software development. The CSM model works with major cycles of core and total product innovations and generates preconditions for rather short project management cycles handling development and delivery of the particular individual product solutions to particular customers.

Even though individual product demand is stressed more in the B2B sector, I am convinced that the CSM concept can also be a good conceptual base for B2C oriented companies.

\section{References}

Akao, Y. (1990) Quality Function Deployment: Integrating Customer Requirements into Product Design Cambridge, MA: Productivity Press.

Baker, W. E., \& Sinkula, J. M. (2015). Market Orientation and Organizational Performance: A New Product Paradox?. In Creating and Delivering Value in Marketing (pp. 254-254). Springer International Publishing. https://doi.org/10. 1007/978-3-319-11848-2_96

Bennett, J., Sharma, D., \& Tipping, A. (2001). Customer solutions: building a strategically aligned business model. Booz Allen \& Hamilton, New York.

Biggemann, S., Kowalkowski, C., Maley, J., \& Brege, S. (2013). Development and implementation of customer solutions: A study of process dynamics and market shaping. Industrial Marketing Management, 42(7), $1083-1092$. https://doi.org/10.1016/j.indmarman.2013.07.026

Boehm, B. W. (1988). A spiral model of software development and enhancement. Computer, 21(5), 61-72. https://doi.org/ $10.1109 / 2.59$

Brynjolfsson, E., \& McAfee, A. (2014). The second machine age: work, progress, and prosperity in a time of brilliant technologies. WW Norton \& Company.

Bureau Van Dijk. (2015) Amadeus. Available from internet: https://amadeus.bvdinfo.com/

Clausing, D. (1994) Quality Development: A Step-by-step Guide to World-class Concurrent Engineering New York: SME Press.

Cohen, L. (1995) Quality Function Deployment: How to Make QFD Work for You Reading, MA: Addison-Wesley.

Drucker, Peter F. (1954), The Practice of Management, New York: Harper and Row Publishers.

Eisenhardt, K. M. (1989). Building theories from case study research. Academy of management review, 14(4), 532-550.

Eisenhardt, K. M. (1991). Better stories and better constructs: The case for rigor and comparative logic. Academy of Management review, 16(3), 620-627.

Franceschini, F., Galetto, M., Maisano, D., \& Mastrogiacomo, L. (2015). Prioritisation of engineering characteristics in QFD in the case of customer requirements orderings. International journal of production Research, 53(13), 3975-3988. https://doi.org/10.1080/00207543.2014.980457

Garcia, R., \& Calantone, R. (2002). A critical look at technological innovation typology and innovativeness terminology: a literature review. Journal of product innovation management, 19(2), 110-132. https://doi.org/10.1016/S0737-678 2(01)00132-1

Gorchels, L. (2003). Transitioning from engineering to product management. Engineering Management Journal, 15(4), 4047. https://doi.org/10.1080/10429247.2003.11415224

Jaworski, B. J., \& Kohli, A. K. (1996). Market orientation: review, refinement, and roadmap. Journal of Market-Focused Management, 1, 119-135. https://doi.org/10.1007/BF00128686

Jones, C., Hesterly, W. S., \& Borgatti, S. P. (1997). A general theory of network governance: Exchange conditions and social mechanisms. Academy of management review, 22(4), 911-945.

Kano, N., Tsuji, S., Seraku, N., \& Takerhashi, F. (1984). Miryokuteki Hinshitsu to Atarimae Hinshitsu. Attractive Quality and Must-Be Quality. Quality, JSQC, 14(2), 39-48.

Kanovska, L., \& Tomaskova, E. (2012). Interfunctional coordination at hi-tech firms. Inzinerine Ekonomika-Engineering Economics, 23(1), 70-76. https://doi.org/10.5755/j01.ee.23.1.1224

Kellen, V., \& Wolf, B. (2003). Business performance measurement. Information Visualization, 1(312), 1-36.

Kohli, A. K., \& Jaworski, B. J. (1990). Market orientation: the construct, research propositions, and managerial implications. The Journal of Marketing, 1-18. https://doi.org/10.2307/1251866 
Vit Chlebovsky. Customer Solutions Management (CSM) Empirical Model based on European Machine Building...

Kohli, A. K., Jaworski, B. J., \& Kumar, A. (1993). MARKOR: a measure of market orientation. Journal of Marketing research, 467-477. https://doi.org/10.2307/3172691

Kotler, P., Rackham, N., \& Krishnaswamy, S. (2006). Ending the war between sales and marketing. Harvard Business Review, 84(7/8), 68.

Lo, M. C., Abang Azlan, M., Ramayah, T., \& Wang, Y. C. (2015). Examining the Effects of Leadership, Market Orientation and Leader Member Exchange (LMX) on Organisational Performance. Inzinerine Ekonomika-Engineering Economics, 26(4), 409-421. https://doi.org/10.5755/j01.ee.26.4.7656

Ma, Y. S., Chen, G., \& Thimm, G. (2008). Paradigm shift: unified and associative feature-based concurrent and collaborative engineering. Journal of Intelligent Manufacturing, 19(6), 625-641. https://doi.org/10.1007/s10845-008-0128-y

Matzler, K., \& Hinterhuber, H. H. (1998). How to make product development projects more successful by integrating Kano's model of customer satisfaction into quality function deployment. Technovation, 18(1), 25-38. https://doi.org/10. 1016/S0166-4972(97)00072-2

Narver, J. C., \& Slater, S. F. (1990). The effect of a market orientation on business profitability. The Journal of marketing, 20-35. https://doi.org/10.2307/1251757

Payne, A., \& Frow, P. (2005). A strategic framework for customer relationship management. Journal of marketing, 69(4), 167-176. https://doi.org/10.1509/jmkg.2005.69.4.167

Prevel Katsanis, L., Laurin, J. P. G., \& Pitta, D. A. (1996). How should product managers' job performance be evaluated in emerging product management systems?. Journal of Product \& Brand Management, 5(6), 5-23. https://doi.org/10. $1108 / 10610429610152804$

Ruekert, R. W. (1992). Developing a market orientation: an organizational strategy perspective. International journal of research in marketing, 9(3), 225-245. https://doi.org/10.1016/0167-8116(92)90019-H

Saxe, R., \& Weitz, B. A. (1982). The SOCO scale: A measure of the customer orientation of salespeople. Journal of marketing research, 343-351. https://doi.org/10.2307/3151568

Schuller, D., \& Videcka, Z. (2016). Product Flow Management of Small and Medium- sized Enterprises. In 3rd International Multidisxiplinary Scientific Conference on Social Sciences \& Art. (pp. 524-531). STEF92 Technology, Ltd., Albena, BG.

Shapiro, B. P. (1988). What the hell is market oriented? (pp. 1/3). HBR Reprints.

Strong Jr, E. K. (1925). Theories of selling. Journal of applied psychology, 9(1), 75. https://doi.org/10.1037/h0070123

Tan, K. C., \& Pawitra, T. A. (2001). Integrating SERVQUAL and Kano's model into QFD for service excellence development. Managing Service Quality: An International Journal, 11(6), 418-430. https://doi.org/10.1108/ EUM0000000006520

Tuli, K. R., Kohli, A. K., \& Bharadwaj, S. G. (2007). Rethinking customer solutions: from product bundles to relational processes. Journal of Marketing, 71(3), 1-17. https://doi.org/10.1509/jmkg.71.3.1

Tyagi, R. K., \& Sawhney, M. S. (2010). High-Performance Product Management: The Impact of Structure, Process, Competencies, and Role Definition. Journal of Product Innovation Management, 27(1), 83-96. https://doi.org/10.1111/j.1540-5885.2009.00701.x

Wasko, M. M., \& Faraj, S. (2005). Why should I share? Examining social capital and knowledge contribution in electronic networks of practice. MIS quarterly, 35-57.

Wasserman, G. S. (1993). On how to prioritize design requirements during the QFD planning process. IIE transactions, 25(3), 59-65. https://doi.org/10.1080/07408179308964291

Webster, F. E. (1988). The rediscovery of the marketing concept. Business horizons, 31(3), 29-39. https://doi.org/10.1016/0007-6813(88)90006-7

Webster Jr, F. E. (1992). The changing role of marketing in the corporation. The Journal of Marketing, 1-17. https://doi.org/10.2307/1251983

Weitz, B. A. (1981). Effectiveness in sales interactions: a contingency framework. The Journal of marketing, 85-103. https://doi.org/10.2307/1251723

Whitley, R. (2006). Project-based firms: new organizational form or variations on a theme?. Industrial and corporate change, 15(1), 77-99. https://doi.org/10.1093/icc/dtj003

Wilson, D. T. (1995). An integrated model of buyer-seller relationships. Journal of the academy of marketing science, 23(4), 335-345. https://doi.org/10.1177/009207039502300414

Womack, J. P., Jones, D. T., \& Roos, D. (1990). Machine that changed the world. Simon and Schuster.

The article has been reviewed.

Received in March, 2016; accepted in December, 2016. 